\title{
DEVELOPMENT OF HIGHER ENGINEERING EDUCATION IN RUSSIA IN THE CONTEXT OF BOLOGNA PROCESS
}

\author{
Chepurin Evgeny ${ }^{1}$, Vasilieva Darya ${ }^{2}$, Vlasov Alexandr ${ }^{2}$, Parsova Velta $^{3}$ \\ ${ }^{1}$ State University of Land Use Planning (Moscow), ${ }^{2}$ Samara State Technical University, \\ ${ }^{3}$ Latvia University of Life Sciences and Technologies
}

\begin{abstract}
The process of reforming higher education in Russian Federation continues. One of the main areas of these reforms is an introduction of principles of Bologna process into Russian higher education system. It was launched after Russia ratified the Bologna Declaration in 2003. Since the beginning of reforms and up to now there have not been lingering disputes about feasibility of introducing the principles of Bologna Agreement into higher education. The article deals with the history of reforms on the example of higher education in land management in Russia. Dynamics of indicators of higher education institutions which carry out training under programs in the field of land management and cadastre have been studied. Introduction of federal state educational standards associated with introduction and/ or updating of current education within Bologna process in 2020 has been considered. Updating (introduction of FGOS 3++ standard) will be implemented in all directions of bachelor degree. First of all it is guided to consideration of requirements of professional standards. The process of development of the Institute of State Accreditation of higher education institutions of Russia, its current status and problems faced by higher education institutions during accreditation process have been studied.

Key words: Bologna Process, engineering education, higher education reform, integration, land management education.
\end{abstract}

\section{Introduction}

Bologna process in European higher education was launched more than 20 years ago, when Bologna Declaration (Joint Statement of European Ministers of Education "European Higher Education Area") was signed on June 19, 1999. Declaration outlined short-term goals, which were supposed to lead to creation of zone of European higher education and promotion of the European system of higher education around the world (Bologna Declaration..., 1999).

The most important objectives of modernization of higher education in Bologna Process were set as follows:

- developing education on the basis of two levels (Bachelor's and Master's degrees);

- introducing a credit system of credit points (ECTS);

- expanding mobility both of students and teachers;

- controlling the quality of education;

- ensuring an employment of graduates;

- promoting European dimensions in higher education;

- making the European education system more attractive.

Integration processes in higher education included first EU Member States and later - other countries within continental Europe and their neighbouring countries. Currently Bologna Process is the largest higher education reform in the history of Europe.

Russian Federation joined to Bologna Process in September 2003 on Berlin Conference, and commitments were made to introduce the basic principles of the Bologna process into higher education until 2010. Since the Bologna Process started, higher education system in Russia has undergone fundamental changes. Integration process is going rather slowly and painfully, there causes many disputes about its expediency, which is noted not only for the Russian Federation, but also for many post-Soviet space countries.

Since September 1, 2009, four-year bachelor's programs were introduced in all higher education institutions in Russia, followed by a master's degree, and admission to a five-year specialist course in most areas was stopped. At present, more than 15 years have passed since Russia's accession to the Bologna Process and some conclusions can be drawn on the development of higher education (Drunk, 2009; Артамонова и др., 2015; Власов, Васильева, 2015; Пьянова, 2009). Assessment of this process 
within higher education community is not unequivocal but there more criticism is dedicated to implementation of the reforms (Востриков и др., 2018; Хеккерт, Боран-Кешишьян, 2019; Чугунов, Ильясова, 2019; Шолохов, 2019).

Implementation of Bologna agreements causes contradictory assessments not only in Russia, but also in Europe. The education scheme proposed by Bologna Declaration differed greatly from the Russian education concept inherited from the Soviet period. The aim of the article is to study development of higher engineering education in Russia under Bologna process implementation conditions on the example of study direction "Land management and cadastre". For this purpose the existing system of training of land surveyors in Russia and characteristics of higher education institutions preparing them have been studied, the changes which have taken place in higher education of the country as a whole, and also in the field land surveyors training during the reforms have been considered, as well as development of the institute of state accreditation of higher education institutions of Russia, its current state and problems have been analysed.

\section{Methodology of research and materials}

Materials of annual statistical reports published by Federal State Statistics Service of the Russian Federation (Rosstat) have been analyzed. Summary data published by Educational and Methodological Council on Education in the field of land management and cadastre have been studied.

\section{Discussions and results}

To implement the land reform, which started in Russia in 1990, there was need for large number of professional staff - cadastre and land management specialists. Land management education in Russia has long history - in 2019 the State University of Land Management (in Moscow) celebrated its 240 anniversary. University was established in 1779 to teach specialists for land reform in Russia [Известия..., 2019]. The University graduates have carried out land reforms, large-scale works on land surveying and rational use of land. Nowadays State University of Land Management is the basic higher education institution in Russia in preparation of bachelors and masters in direction "Land management and cadastre". At the University there has been created Educational and Methodical Council (further EMC). It is attended by representatives of universities from different regions of Russia, where students have been prepared in this field. At present the number of appropriate universities has increased significantly. In Soviet period on territory of Russian Federation there were 5 universities in land management, in $2019-107$ (Table 1).

Table 1

Dynamics of number of higher education institutions in direction of studies "Land management and cadastre"

\begin{tabular}{|c|c|c|c|}
\hline \multirow{2}{*}{ Indicators } & \multicolumn{3}{|c|}{ Year } \\
\hline & 2017 & 2018 & 2019 \\
\hline Total number of universities, including: & 98 & 104 & 107 \\
\hline - under Ministry of Agriculture of Russia & 37 & 40 & 40 \\
\hline - under Ministry of Education and Science of Russia & 61 & 64 & 67 \\
\hline Total number of universities - members of EMC, including: & 94 & 98 & 100 \\
\hline \begin{tabular}{|l|l} 
& total number of students enrolled, including: \\
\end{tabular} & 6980 & 7295 & $\mathbf{7 2 4 4}$ \\
\hline - bachelor studies & 5528 & 5697 & 5799 \\
\hline - Master studies & 1395 & 1527 & 1387 \\
\hline - PhD studies & 57 & 71 & 58 \\
\hline total number of graduates & 6097 & 5933 & 6216 \\
\hline - bachelor studies & 5379 & 4963 & 5026 \\
\hline - Master studies & 672 & 936 & 1159 \\
\hline - PhD studies & 46 & 34 & 31 \\
\hline $\begin{array}{l}\text { Annual total number of students (from enrollment to } \\
\text { graduation) }\end{array}$ & 25593 & 26873 & 25400 \\
\hline
\end{tabular}

Source: data of EMC (Подготовка кадров..., 2020) 
In general, due to beginning of land reform in Russia, enrolment of students into higher education institutions for surveying studies has increased significantly. In 1991 throughout the country, there were only 675 enrolled students, because only 4 universities in the Russia prepared specialists in land surveying, land management and cadastre. When the land reform began, there come out the lack of specialists who could carry it out. Urgently were opened appropriate study programs - first in agrarian universities, then in others. In 2019 total number of enrolled students in bachelor, Master and PhD studies exceeded 7 thousand.

As showed data of EMC, in 2019 number of enrolled bachelor level students is more than 4 times higher than number of enrolled Master level students. Less than $30 \%$ of bachelor level graduates continue their studies at Master level on speciality "Land Management and Cadastre". In Russia it is allowed to study on Master level after obtaining of Bachelor's degree or having the diploma of engineer - land surveyor (before implementation of Bachelor's degree). On Master level studies can be enrolled not only land management and cadastre specialists, but graduates with Bachelor's degree of the same kind of specialities.

Studying the location of higher education institutions according federal regions of Russia, there can be noted significant differences - the maximum number are located in Tsentralnyy (24) and Privolzhskiy (21) region, the minimum number - in Dalnevostochniy (9), Uralskiy (9) and Severo-Kavkazskiy (8) region (Table 2)

Table 2

Breakdown of universities having study programs in field of land management and cadastre (2019)

\begin{tabular}{|c|c|c|c|c|c|c|c|c|c|c|}
\hline \multirow[t]{3}{*}{$\begin{array}{c}\text { Federal } \\
\text { region (Oblastj) }\end{array}$} & \multicolumn{3}{|c|}{$\begin{array}{c}\text { Number of } \\
\text { universities }\end{array}$} & \multirow{3}{*}{ 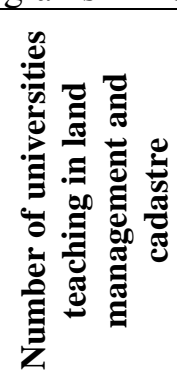 } & \multicolumn{3}{|c|}{$\begin{array}{c}\text { Number of study } \\
\text { programs }\end{array}$} & \multirow{3}{*}{ 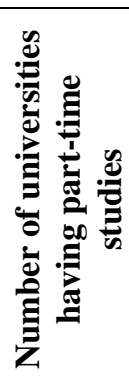 } & \multicolumn{2}{|c|}{$\begin{array}{c}\text { Number of } \\
\text { teachers }\end{array}$} \\
\hline & \multirow[t]{2}{*}{ total } & \multicolumn{2}{|c|}{ including } & & $\Phi$ & $\overline{0}$ & & & total & \\
\hline & & 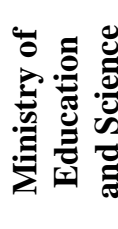 & 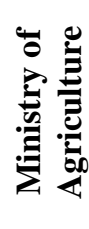 & & 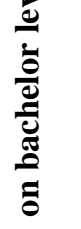 & $\frac{\overrightarrow{0}}{\sum_{\bar{v}}^{5}}$ & 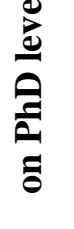 & & & 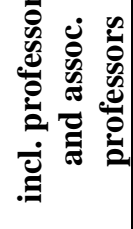 \\
\hline Dalnevostochniy & 9 & 5 & 4 & 9 & 9 & 7 & 0 & 7 & 82 & 50 \\
\hline Privolzhskiy & 21 & 10 & 11 & 21 & 21 & 12 & 1 & 17 & 273 & 207 \\
\hline Severo-Zapadniy & 13 & 12 & 1 & 12 & 13 & 7 & 3 & 9 & 161 & 125 \\
\hline Severo-Kavkazskiy & 8 & 4 & 4 & 8 & 8 & 6 & 1 & 8 & 88 & 68 \\
\hline Sibirskiy & 11 & 7 & 4 & 9 & 11 & 9 & 4 & 8 & 194 & 138 \\
\hline Uralskiy & 9 & 6 & 3 & 9 & 9 & 3 & 3 & 7 & 91 & 64 \\
\hline Tsentralnyy & 24 & 15 & 9 & 21 & 22 & 12 & 6 & 20 & 400 & 299 \\
\hline Yuzhnyy & 12 & 8 & 4 & 11 & 12 & 7 & 2 & 10 & 128 & 107 \\
\hline Total & 107 & 67 & 40 & 100 & 105 & 63 & 20 & 86 & 1417 & 1058 \\
\hline
\end{tabular}

Source: data of EMC (Подготовка кадров..., 2020)

Data show that number of universities which realised enrolment in 2019, is higher than number of universities which in realised graduation. This fact indicates that in recent years the licensing process and opening of new bachelor and Master study programs in field of land management and cadastre is going on in Russia. At the same time the total number of universities in Russia has decreased from 1115 in academic year 2010-2011 to 742 in academic year 2018-2019 (Российский статистический ежегодник, 2018). Reduction in the number of universities by $33 \%$ coincided with reduction in number of students by $41 \%$ due to negative demographic tendencies. Licenses of ineffective educational institutions were nullified by the Ministry of Education as well. Number of professors and teachers has also decreased (Пинтаева, 2019).

In early 1990s training of specialists in field of land management and cadastre was carried out according to only curriculum of specialty "Land management" (5 study years), which was approved by Ministry of Agriculture of the Russia. This curriculum clearly defined study disciplines, field practices and practical trainings. In 1992 there started an experiment for implementation of multilevel system of teaching granting degree "Bachelor of land management" (4 study years), and "Master of land management" ( 2 study years). Unfortunately, small number of higher education institutions participated 
in this experiment. Since 1992 the number of specialties has been expanded, there appeared specialties "Land cadastre" and "Urban cadastre", and first generation of National Educational Standards were accepted. These standards were used until 2000.

Second generation of education standards were introduced in 2000. They defined general requirements, structure and conditions of teaching and specified the set of necessary disciplines. Direction of studies "Land management and cadastre", which included three specialities ("Land management", "Land cadastre" and "Urban cadastre") were moved from sector "Agricultural sciences" to sector "Technics and technology". Curricula for second generation of education standards could include so-called "regional component" - universities could introduce specific regional disciplines.

Implementation of Bologna Process into higher education of Russia also had an impact on preparation of specialists in field of land management and cadastre. On September 1, 2009 bachelor's program was introduced in all higher education institutions in Russia with subsequent specialization on Master level. Gradually old system of teaching was reduced, and now modern legislation and National Educational Standards fully are based on two-level system "bachelor degree - Master degree". The legislation considers bachelor degree and Master degree as independent educational levels of higher education with separate educational standards and independent final certification. Licensing and state accreditation of higher education institutions in respect to bachelor and Master programs are also carried out separately. In 2011 new, third-generation educational standards, based on competence approach, was implemented, which gave greater academic freedom to universities to include study disciplines in the curriculum. Direction of teaching was named "Land management and cadastre".

In 2015 this direction was included in the enlarged group of specialties and directions of teaching "21.00.00 Applied geology, mining industry, oil and gas industry and geodesy", which is referred to the field of education "Engineering, technology and technical sciences". In 2015 EMC on education in the field of land management and cadastre, created at the State University of Land Management already in 1987, was included into National EMC "21.00.00 Applied geology, mining industry, oil and gas industry and geodesy". EMC participates in development of National educational standards for higher education, exemplary basic educational programs, Curricula, methodological literature, as well as in international European educational projects. Annual meetings of representatives of universities and National competitions for best qualification work of graduates in more than 10 categories take place.

At present decisions of EMC has only recommendatory status, therefore the difference in content of curricula in study direction "Land management and cadastre" is increasing. In such situation the academic mobility of students practically is unattainable, because cross-comparison of disciplines is impossible due to name (title) of discipline rather than volume of credits. In higher education of Russia yet it has not been possible to create conditions for students to form their own educational trajectories, because there is lack of disciplines by choice.

Academic mobility both for students and teachers is a problem due to low level of income. In addition, poor knowledge of foreign languages, especially English, of teachers and students is barrier for mobility. It should be noted that there is a very low awareness among university teachers about basic principles of Bologna Process. Many of them it understands only as replacement of five-year studies with bachelor's and master's degree, and they have rather negative attitude to these reforms (Ким, 2017).

In order to comply with legal norms in the field of higher education, all as well as to control the quality of education in higher education, Ministry of Higher Education and Science of Russian Federation conducts control and supervision activities. At present in the field of education the regulation includes:

- licensing, including control over licensing process;

- accreditation process;

- control (supervision).

Accreditation of educational activities in accordance with Federal Law "On education in the Russian Federation" is divided into state, public, professional and international accreditation. At present state accreditation takes the form of on-site and documentary inspections, but in 2020 new model of state control is proposed to be implemented (Федеральный закон..., 2012).

Important stage in the process of reforming the Russian education system is the transition to new generation of educational standards as close as possible to national professional standards in terms of functions and competencies necessary on labour market. In order to maintain the compliance of educational standards with modern requirements of the labour market, they should be regularly updated. 
It is planned to update in 2020 the educational standards of third generation (FGOS 3++). Forming the new standards, there are three types of competences - comprehensive cultural competences, comprehensive professional competences and comprehensive professional competences. Comprehensive (universal) cultural competences are the single set of competencies for bachelor's or master's degree level of education, which is regulated by Ministry of Higher Education and Science of the Russian Federation. Comprehensive professional (sector) competences are established by federal Educational and methodical association and are unified for enlarged groups and areas of training and specialities. Comprehensive professional competences are formed on the basis of professional standards. Educational standard allows introduce additional competencies that provide specific targeted professional activities and functions defined by customer (enterprises and companies) requirements.

New standards will contain:

- clearly elaborated system of internal evaluation of education quality;

- possibility to evaluate education process (conditions, content and quality, etc.) by students;

- involvement of employers and their associations in regular evaluation of the quality of educational activities;

- external evaluation of educational activities on voluntary basis.

Academic freedom in universities remains as problematic issue. Universities have the right to establish the so-called "profiles" in the educational programme. For bachelor program in "Land management and cadastre" such profiles are digital land management, real property cadastre, real property management, agricultural land monitoring, real property valuation, assessment and management of urban areas, legal, geodetic and informational support for land management and cadastre, and others.

The process of implementation of educational program network, which will allow for students to choose individual training courses, disciplines (modules), practices in other educational and scientific organizations, is going on.

\section{Conclusions and proposals}

At present in Russia the reform of higher education system, including engineering specialities, continues. This process is part of modernization of higher education, which started after signing of Bologna Declaration in 2003. Bologna Process is aimed to create the pan-European education space, it represents the most significant structural reform of higher education in its history.

The results of implemented reforms have been assessed ambiguously and there are both positive and negative consequences. As positive can be mentioned:

- integration of Russian education system into educational space of the world and mutual recognition of education documents;

- increase in academic and student mobility;

- unification of competence assessment according pan-European systems (credit rating, etc.);

- increase in competitiveness of Russian higher education institutions;

- expansion of participation in international scientific competitions and grants, forums and exhibitions, in international organizations and associations;

- increase in participation in international competitions, forums and exhibitions;

- increase in scientific and publishing activity within international citation systems Web of Science and Scopus;

- dissemination of knowledge and technologies, registration and implementation of the results of intellectual activity at the international level.

As negative consequences can be mentioned:

- increased bureaucratization of educational process;

- complicate system of credit points (ECTS) and complexity of its implementation;

- duplication of quality control functions at various levels;

- absence of ideas about the basic principles, goals and objectives of Bologna process leads to formal attitude to the changes taking place and to the general non-acceptance of the reforms.

There can be made general conclusions as follows:

1. Existing system of education of land surveyors in Russia has long history, currently is developing very actively. The number of universities training bachelors and masters in the field of land surveying and cadastre is increasing in spite of general decrease of total number of universities. 
2. Within framework of Bologna Process two-level system for training of land surveyors was introduced in higher education in Russia - bachelor program (4 years) and Master program (2 years). At the same time employers prefer to employ graduates with Master diploma and engineers - land surveyors, bachelors are considered in case if they have practical experience and recommendations.

3. Possibility to change direction of training at enrollment in Master program leads to heterogeneity of levels of knowledge among students. It affects negatively the efficiency of educational process and requires the teacher to make additional efforts in the context of limited classroom hours.

4. Accreditation of higher education institutions is the mechanism how to control compliance with legislative requirements and the quality of training of students at higher education institutions.

\section{References}

1. Bologna Declaration "European Higher Education Area" (1999) Joint Declaration of the European Ministers of Education of Bologna, 19 June 1999. URL: http://www.msmsu.ru/userdata/manual/images/fac/ped_obr/Bolonskaja_deklaracija.pdf.

2. Drunk O.A. (2009) The essence of the Bologna process in the European educational space and reasons of joining of Russia to this process // Innovative education and economy. №4 (15). Pp. 23-24.

3. Артамонова Ю.Д., Демчук А.Л., Камынина Н.Р., Котлобовский И.Б. (2015) Российское высшее образование в Болонском процессе (По материалам национального доклада РФ) (Russian higher education in the Bologna Process (Based on the national report of the Russian Federation)). Высшеe образвоание в России. №8-9. С. 46-53. (in Russian)

4. Востриков В.Н., Лищук Е.Н., Савченко Н.В. (2018) Плюсы и минусы Болонского процесса в российском высшем образовании (Pluses and minuses of the Bologna process in Russian higher education). Символ науки. 2018. №8. C. 51-59. (in Russian)

5. Власов А.Г., Васильева Д.И. (2015) Сравнительный анализ образовательных стандартов ФГОС ВПО и ФГОС ВО (ФГОС 3+) по направлению «Землеустройство и кадастры» (Comparative analysis of educational standards of FSES HPE and FSES ETO (FSES 3+) in the field of "Land management and cadastres") // Региональное развитие, №1 (5), 2015. С.1-6. (in Russian)

6. Ким И.Н. (2017) О влиянии Болонского процесса на развитие высшего образования в России // Инженерное образование (About influence of the Bologna process on development of higher education in Russia) №22. C. 96-100. (in Russian)

7. Пинтаева М.Ю. (2019) Высшее образование России и Болонский процесс (Higher education of Russia and the Bologna process) Мировая наука. №5(26). С. 353-358.

8. Подготовка кадров по направлению «Землеустройство и кадастры» в системе высшего образования Российской Федерации (Сводные данные на 01.09.2019г.) (2020) (Training in the field of land management and cadastres in the system of higher education of the Russian Federation (Consolidated data as of 01.09.2019)) Составители: Е.М. Чепурин, А.П. Спиридонова, Е.А Счастливецкая. Москва: ГУЗ. 56 c. (in Russian)

9. Пьянова О.А. (2009) Сущность Болонского процесса в европейском образовательном пространстве и причины присоединения России к этому процессу (The essence of the Bologna Process in the European educational space and reasons for Russia's joining this process) Инновационное образование и экономика. №4 (15). C. 23-24. (in Russian)

10. Российский статистический ежегодник (2018). (Russian Statistical Yearbook) M. Росстат. URL: http://www.gks.ru/wps/wcm/connect/rosstat_main/rosstat/ru/statistics/publications/catalog/doc 1135087342

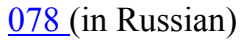

11. Федеральный закон "Об образовании в Российской Федерации" (2012) (Federal Law "On Education in the Russian Federation" ) от 29.12.2012 N 273-Ф3 (in Russian)

12. Хекерт Е.В., Боран-Кешишьян А.Л. (2019) Российское морское образование в Болонском процессе (Russian maritime education in the Bologna Process) Эксплуатация морского транспорта. №3. C. 12-19. (in Russian)

13. Чугунов А.С., Ильясова А.М. (2019) Болонский процесс как способ интеграции высшего образования стран Европы и РФ (The Bologna Process as a way to integrate higher education in Europe and the Russian Federation) Казанский вестник молодых ученых. Том 3. № 2. С. 121-126. (in Russian)

14. Шолохов А.В. (2019) «Болонский процесс» как генератор перманентного кризиса в российском высшем образовании (The «Bologna Process» as a generator of a permanent crisis in Russian higher education) Международный журнал гуманитарных и естественных наук. № 1-1. С. 87-90. (in Russian) 
Information about authors:

Evgeny Chepurin. Candidate of Economic Sciences, Professor of the Department of Land Management of the State University on Land Use Planning. Address: Russia, 105064, Moscow, Kazakova str. 15, phone +7(915) 08054-21, e-mail: umo-guz@mail.ru

Alexander Vlasov. PhD, Head of the Department of Land Management and Cadastre of Samara State University of Economics. Address: Russia, 443090, Samara, Soviet Army street 141, of Latvia University of Life Sciences and Technologies. Address: 19, Akademijas str., Jelgava, LV-3001, phone +7(937) 799-08-86, e-mail: kafzik@yandex.ru

Darya Vasilieva. PhD, Associate Professor of the Department of Land Management and Cadastre of Samara State University of Economics. Address: Russia, 443090, Samara, Soviet Army street 141, of Latvia University of Life Sciences and Technologies. Address: 19, Akademijas str., Jelgava, LV-3001, phone +7(927) 200-30-78, e-mail: vasilievadi@mail.ru

Velta Parsova. Dr.oec., professor, Department of Land Management and Geodesy of Latvia University of Life Sciences and Technologies. Address: 19, Akademijas str., Jelgava, LV-3001, phone: +371 29118285, e-mail: velta@parsova.lv 